\title{
Does COVID-19 effects the United States crude oil imports price?
}

\section{KEYWORDS}

crude oil price;

total death;

total cases;

COVID-19;

ARDL model

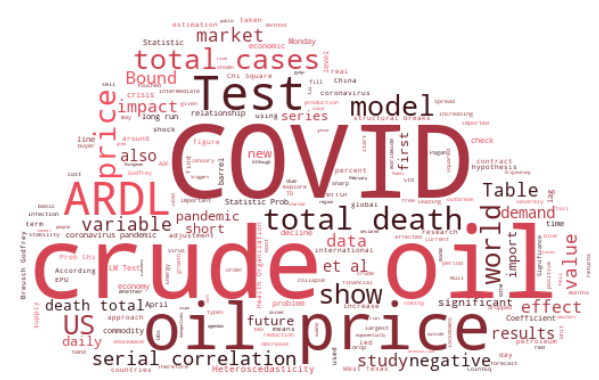

Word Cloud Generated by:

https://wordscloud.pythonanywhere.com/

\section{ABSTRACT}

Introduction. The outbreak of the new coronavirus (COVID-19) crisis monopolizes these days the worldwide public agendas. The COVID-19 pandemic makes fear and uncertainty, defeat the world economy and swelling the financial markets instability. The coronavirus pandemic has led the global economy to slam the brakes, leading to an extremely sharp drop in demand for oil. It has created a massive oil glut and raised concerns about the lack of physical storage space for it.

Materials and Methods. The autoregressive distributed lag (ARDL) model has been used for decades to study the correlation between variables using a single equation time series. The ARDL model is one of the most common dynamic unrestricted models in econometric literature. In this model, the dependent variable is expressed by the lag and current values of independent and its own lag value.

This paper analyzed the effect of COVID-19 pandemic on the United States (US) Crude oil imports prices, using daily data for the period December 31, 2019 to March 21, 2020. Using the ADF test for stationary and bounds testing approach to cointegration, developed within an ARDL model.

Results. Finding of the study showed that the total death, have significant consequence on the crude oil price, the adverse effect shows, if 1 percent increase in total death leads to decrease the crude oil - 0.001 percent. The total cases are also negative effect the crude oil price, mean one percent increase in the COVID-19 which lead to decrease crude oil price -10.23.

Discussion and Conclusion. The contuse increasing of COVID-19 pandemic generates shock waves on the crude oil markets, as well as in the real economy of US and also in the world. The deepness of the new economic recession will depend on the policy reaction to the coronavirus. This research paper analyzes how the COVID-19 total death and total cases effect the US crude oil price.

The results of the study show that the world COVID-19 total death is significant impact on the crude oil price, if one percent increase in the total death in the world which lead decrees the crude oil price. The total cases of COVID-19 also have negative and significant effects the crude oil price.

Ahmad, Sh. (2021). Does COVID-19 effects the United States crude oil imports price? Economic consultant, 33 (1), 57-67. doi: 10.46224/ ecoc.2021.1.6 


\section{INTRODUCTION}

$\mathrm{T}$ he outbreak of the new coronavirus (COVID-19) crisis monopolizes these days the worldwide public agendas. Originating in China (Hubei region), the COVID-19 affected over the last two months over 100,000 people and more than 100 countries. The World Health Organization (WHO), which daily monitors the COVID-19 figures since January 21, 2020, declared the coronavirus a pandemic. Although the spread of the virus started to decline, after the middle of February in China, the infection cases grew exponentially outside China. The European countries, but also the United States (US), are now severely touched. On the on hand, the COVID-19 triggers fear and anxiety in the society, nourished both by the daily reported new infection cases and by the increasing fatality ratio. On the other hand, the virus starts to affect the real economy, generating a crash on financial and commodity markets, and crude oil price [1]. The COVID-19 pandemic and the consequent economic lockdowns globally have disrupted the global supply chains and reduced aggregate demand [18]. A sharp reduction oil consumption due to lockdowns led to a drastic decline in crude oil prices in the international market, from US \$61 on January 2, 2020 to US\$ 12 on April 28, 2020 [17].

In the spring of 2020, oil prices collapsed amid the COVID-19 pandemic and economic slowdown. A decline in oil price reduces the cost of production and increase economics growth [15]. The dramatic collapse in worldwide demand for oil led to an extraordinary development on Monday: U.S. oil prices fell below zero for the first time ever, and kept falling. Most of the petroleum imported by the U.S. is crude oil (70-80\% of total petroleum imports, varying slightly from year to year). Because of the country's extensive refining capabilities, particularly near major ports on the Gulf Coast, refined products have historically made up the vast majority of U.S. In the third quarter of 2018, the U.S. imported roughly 10.2 million barrels of petroleum per day, with the largest amounts coming from Canada (41\%) and Saudi Arabia (10\%).

The coronavirus pandemic has led the global economy to slam the brakes, leading to an extremely sharp drop in demand for oil. It has created a massive oil glut and raised concerns about the lack of physical storage space for it. According to Barsky and Kilian [6] the price of crude oil is determined in global market. A useful approach to classifying the key determinants of the real price of oil.

The specific sell-off on Monday is partly due to market mechanics, because the May futures contract for West Texas Intermediate is about to expire. During normal times, traders just sell these contracts and roll on to those of future months. But now, buyers that are capable of receiving and storing that much oil are in short supply. The prices of other types of crude, without a deadline coming up that quickly, have not dropped nearly so sharply. But in general, crude oil prices are very low and continue to fall. Brent, an international benchmark, is in the mid- $\$ 20$ s and fell more than $9 \%$ on Monday.

At the start of 2020, a barrel of West Texas Intermediate cost around \$60. Prices had dropped swiftly because of the coronavirus, landing at around \$18 a barrel on Friday, 
ahead of Monday's big dive. The idea of a negative price for any commodity is outlandish, implying the seller is prepared to pay a buyer. But for oil, the largest commodity market in the world, the basic fuel of modernity, to be trading at negative prices is nothing short of mind-boggling. In the early afternoon EDT of April 20, the May contract for West Texas crude touched negative $\$ 40.32$. It was a succinct demonstration of how severe the impact of the COVID-19 crisis has been.

What triggered the inversion of prices on April 20 was the overflow of unsellable oil in the tank farms of Cushing, Oklahoma, where U.S. oil futures are settled. But the collapse in oil prices has sent shockwaves rippling around the world. Offshore oil platforms are seen on April 20, 2020 in Huntington Beach, California. Oil prices traded in negative territory for the first time as the spread of coronavirus (COVID-19) impacts demand.

This is new study on COVID-19 impact on import price of crude oil of US. The determinate of crude oil price has already been investigated. Chen et al. [7] show the that the effect of oil price shocks on EPU is positive impact at all frequencies, the same study conduct by Antonakakis et al. [5]. According to the Ma et al. [12] that the EPU is important to forecast oil futures prices, whereas Aloui et al. [3] show that the EPU influences the oil price returns only in certain periods. Our study focuses on the current condition cause by COVID-19 crisis. Therefore, we fill in the research gap and test the impact of COVID-19 total cases, total death and crude oil imports price of US. According to Qin et al. [20] find that the COVID-19 pandemic caused a reduction in oil demand leading to a decline in oil price. Similarly, Alana and Monge [11] find that the COVID-19 pandemic made the oil market inefficient, and in turn, oil price difficult to forecast. The Liu, Wan and Lee [11] show that the COVID-19 outbreak had a positive impact on crude oil and stock returns. In the current COVID-19 phase, we have seen that the equilibrium crude oil prices come from the adjustment of oil supply and demand. The estimation, for example, by the International Energy Agency shows a daily drop of 435 thousand barrels, and the OPEC has reacted by cutting oil production [8]. While the empirical literature has extensively shown the role of various types of uncertainties on crude oil prices $[1 ; 8 ; 13]$ there is no work exploring the effect of CVID-19 shocks related to crude oil prices. In this research study, we explore to fill this gap and focus on the degree of persistence inherent in the crude oil price series.

\section{MATERIALS AND METHODS}

Using daily data for the period December 31, 2019 to March 21, 2020, The COVID-19 daily data was taken from World Health Organization (WHO), the total death and total cases data in the world. The crude oil price of us import taken from US Energy Information Administration. The methodology of this research study involves the effect of COVID-19 on US crude oil imports prices. 
New confirmed deaths, by date of report $(n=1,711,485)$

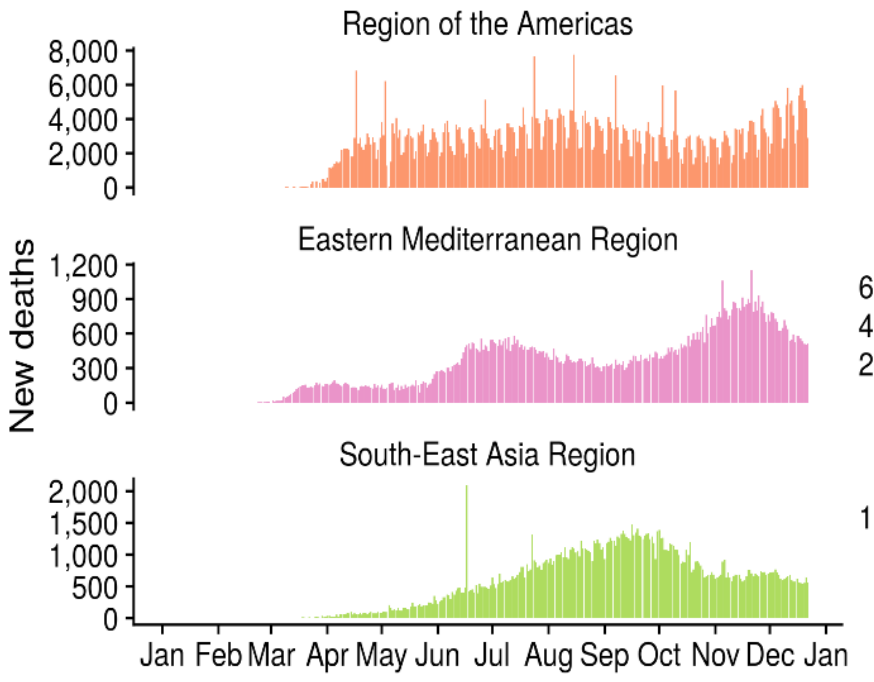

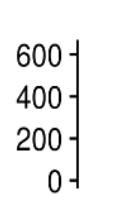
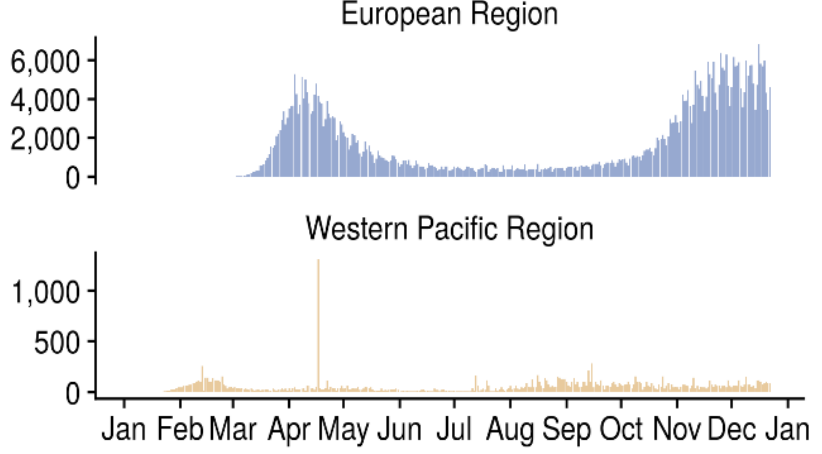
Date of report

\section{O Region African Region Eastern Mediterranean Region \\ European Region \\ South-East Asia Region Western \\ Data for international conveyances not shown Source: COVID Intel database}

\section{New confirmed cases, by date of report $(n=76,857,762)$}

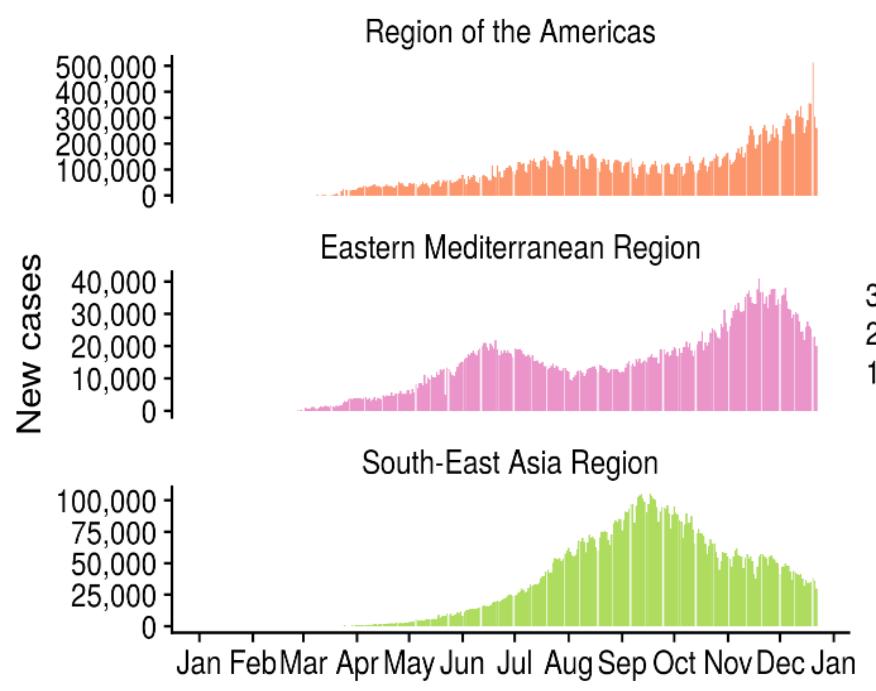

$$
\begin{array}{r}
20,000-1 \\
15,000-1 \\
10,000-1 \\
5,000-1 \\
0
\end{array}
$$

$$
\begin{array}{r}
300,000- \\
200,000 \\
100,000 \\
0
\end{array}-
$$

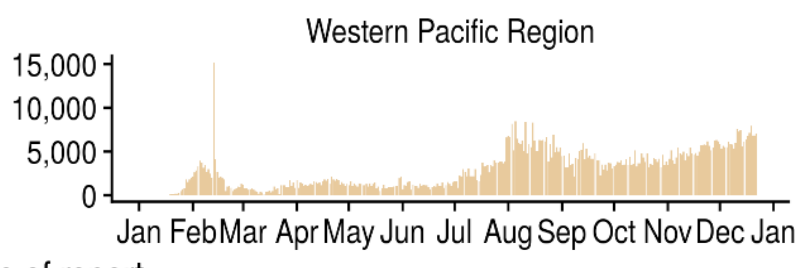

Date of report

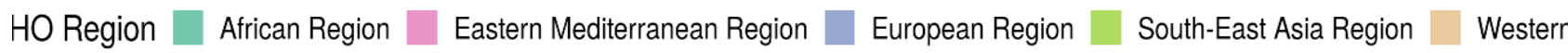 Data for international conveyances not shown Source: COVID Intel database

The basic equation is given below,

$\triangle E P U_{t}=\propto+\beta_{E P U} E P U_{t-1}+\beta_{\text {COVID }-19}$ COVID $-19_{t} \beta_{o i l} O_{i l} l_{t-1}+\sum_{i=1}^{p} \alpha_{i} \Delta E P U_{i-t}+$ $\sum_{i=1}^{p} \beta_{i} \Delta C O V I D-19_{t-i}+\sum_{i=1}^{p} \delta_{i} \Delta O i l_{t-i}+\theta_{i} E C T_{t-i}+\epsilon_{t}$

where (I) $\beta$ and $\Delta$ are short and long run terms respectively, i represents the maximum number of lags, the error correction adjustment term is denoted by ECT and the speed of adjustment is $\theta$ and $\varepsilon$ is the error term. 
Tests conducted per new confirmed case of COVID-19, Dec 22, $2020 \quad \begin{gathered}\text { Our World } \\ \text { inData }\end{gathered}$ Shown is the daily number of tests for each new confirmed case. This is a rolling 7-day average.
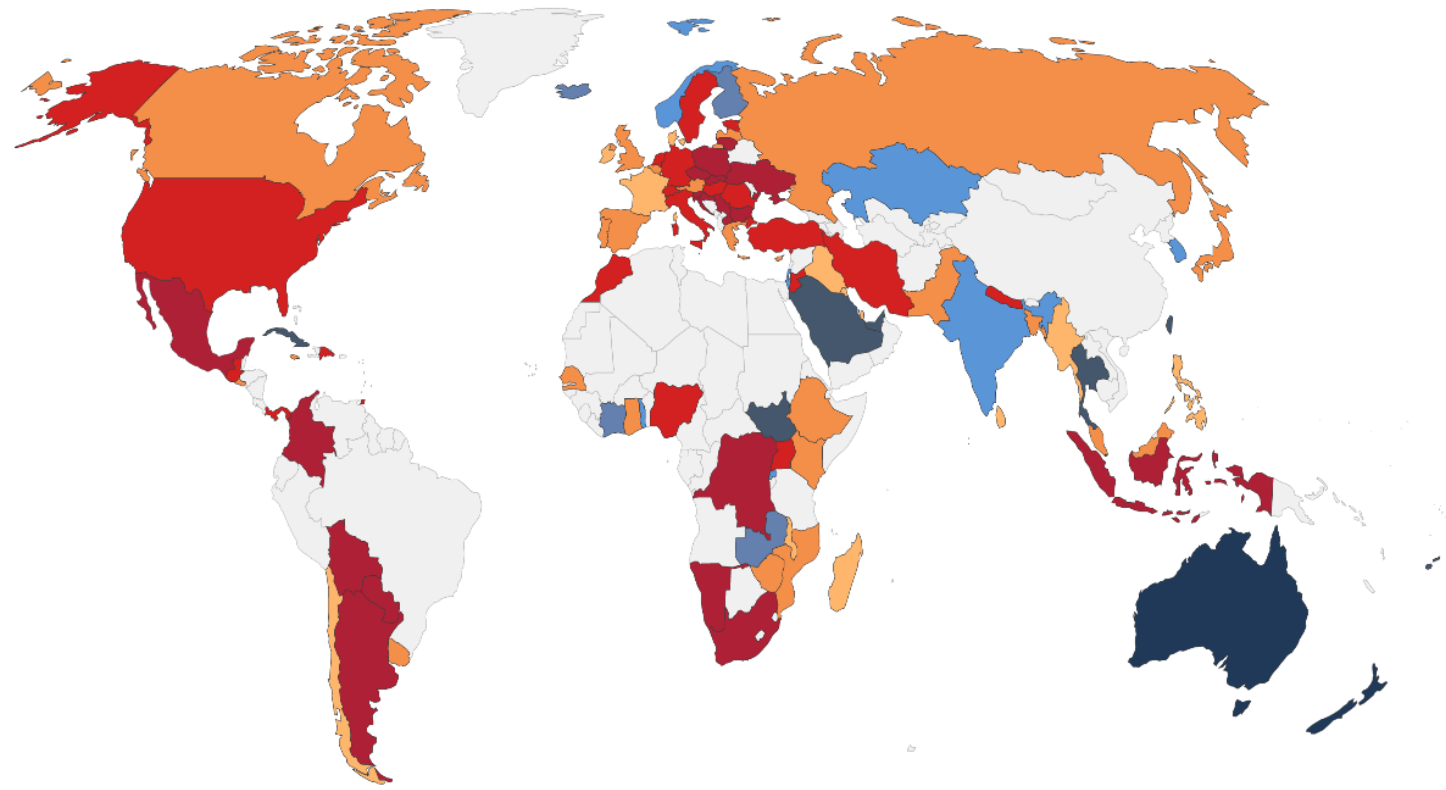

No data 0

5

10

20

30

50

100

1,000

$>5,000$

Source: Official data collated by Our World in Data

OurWorldlnData.org/coronavirus • CC BY

Note: Comparisons of testing data across countries are affected by differences in the way the data are reported. Daily data is interpolated for countries not reporting testing data on a daily basis. Details can be found at our Testing Dataset page.

Figure show the COVID-19 total death and total cases in the world. The figure shows an exponential growth pattern for the 116-day data taken from World Health Organization (WHO).

\section{COVID-19}

3000000

2500000

2000000

1500000

1000000

500000

31120701140121012801040211021802250203031003170324033103070414042104

$\begin{array}{lllllllllllllllll}19 & 20 & 20 & 20 & 20 & 20 & 20 & 20 & 20 & 20 & 20 & 20 & 20 & 20 & 20 & 20 & 20\end{array}$

Total Death $\longrightarrow$ Total Cases 


\section{RESULTS}

Table 1

Unit Root Test ADF

\begin{tabular}{|l|ccc|}
\hline & Crude Oil & COVID-19TC & COVID-19TD \\
\hline Level & -0.83 & $-2,31$ & $-3.36^{*}$ \\
\hline First Difference & $-6.46^{*}$ & $-3.47^{*}$ & $-3.92^{*}$ \\
\hline
\end{tabular}

*Significant at 5\%

TC: Total Cases TD: Total Death

The above table 1 show that the results of augmented Dickey-Fuller unit root test and confirm that all the variable are mixes such is the one variable is on level and the other variables is order one. So the ADF test decide the ARDL model for estimation. Given that our series are either level and order fist, we use the ARDL model proposed by [18] to examine the effect of COVID-19 on crude oil price.

\section{Autoregressive Distributed Lag (ARDL) Model}

We used ARDL approach of Pesaran et al. [17] to check for the existence of relationship among the variables. This approach can be applied to series of irrespective whether they are 1(0), 1(1) or mutually integrated. The ARDL model has good advantages over different approaches, first, the series used do no longer to be 1(1) [18]. Laurenceson and Chai [10] indicated that ARDL method overcomes the problem resulting from non-stationary time series data. ARDL is also applicable and effective in estimation of both small and infinite sample size.

Table 2

ARDL Short Run

\begin{tabular}{|l|c|c|c|c|}
\hline \multicolumn{5}{|c|}{ Cointegrating Form } \\
\hline \multicolumn{1}{|c|}{ Variable } & Coefficient & Std. Error & t-Statistic & Prob. \\
\hline D(Crude oil(-1)) & 0.445739 & 0.091656 & 4.863176 & 0.0000 \\
\hline D(Crude oil(-2)) & -0.138821 & 0.096411 & -1.439897 & 0.1529 \\
\hline D(Total Death) & -0.000406 & 0.000712 & -0.570347 & 0.5697 \\
\hline D(Total Death(-1)) & 0.001711 & 0.000763 & 2.240726 & 0.0271 \\
\hline D(Total Cases) & -0.702540 & 0.247874 & -2.834262 & 0.0055 \\
\hline CointEq(-1) & -0.064607 & 0.023521 & -2.746770 & 0.0071 \\
\hline Cointeq = RP - (-0.0010*TD -10.8740*LTC + 178.7791) \\
\hline
\end{tabular}

Above are the results of ARDL short run in which we chose two lags suggested by Schwarz info Criteria for each variables. After the selection of thee lag we further check that model has a serial correlation problem or not and also check the stability of model. 
Table 3

ARDL Long Run

\begin{tabular}{|l|c|c|c|c|}
\hline \multicolumn{1}{|c|}{ Variable } & Coefficient & Std. Error & t-Statistic & Prob. \\
\hline Total Death & -0.001014 & 0.000497 & -2.037569 & 0.0441 \\
\hline Total Cases & -10.873974 & 2.967644 & -3.664178 & 0.0004 \\
\hline C & 178.779121 & 27.428195 & 6.518078 & 0.0000 \\
\hline
\end{tabular}

Above are ARDL long run results. Here the dependent variable is crude oil price. Total Death of COVID-19 has negative but significant relationship with crude oil. Here the Total Death coefficient value is -0.001014 , means that if 1 percent increase in total death leads to decrease crude oil price.

Total cases of COVID-19 have also negative and significant relationship with crude oil. Here the total cases of COVID-19 coefficient value are -10.87 , means that if 1 percent change in total cases of COVID-19, so it tends to decrease the crude oil price.

\section{Bound Test}

Table 4

ARDL Bound Test

\begin{tabular}{|l|c|c|}
\hline Test Statistic & Value & $\mathrm{K}$ \\
\hline F-statistic & 5.462408 & 2 \\
\hline Critical Value Bounds & & \\
\hline Significance & I(0) Bound & I(1) Bound \\
\hline $10 \%$ & 3.17 & 4.14 \\
\hline $5 \%$ & 3.79 & 4.85 \\
\hline $2.5 \%$ & 4.41 & 5.52 \\
\hline $1 \%$ & 5.15 & 6.36 \\
\hline
\end{tabular}

Above are the results of ARDL bound test in which the F-Statistic value is greater than upper bound at $5 \%$ level. So, we concluded that there is long run relationship exists.

\section{DIAGNOSTICS TESTS}

\section{Cu sum Test}

The Cu sum test is used to check the whether there are structural breaks in the data are not if the blue line fall or remain in the red line. Then the model is stable or free from structural breaks and vice versa.

The blue line within the red lines which shows the stability of the model. It means the model is free from structural breaks. 

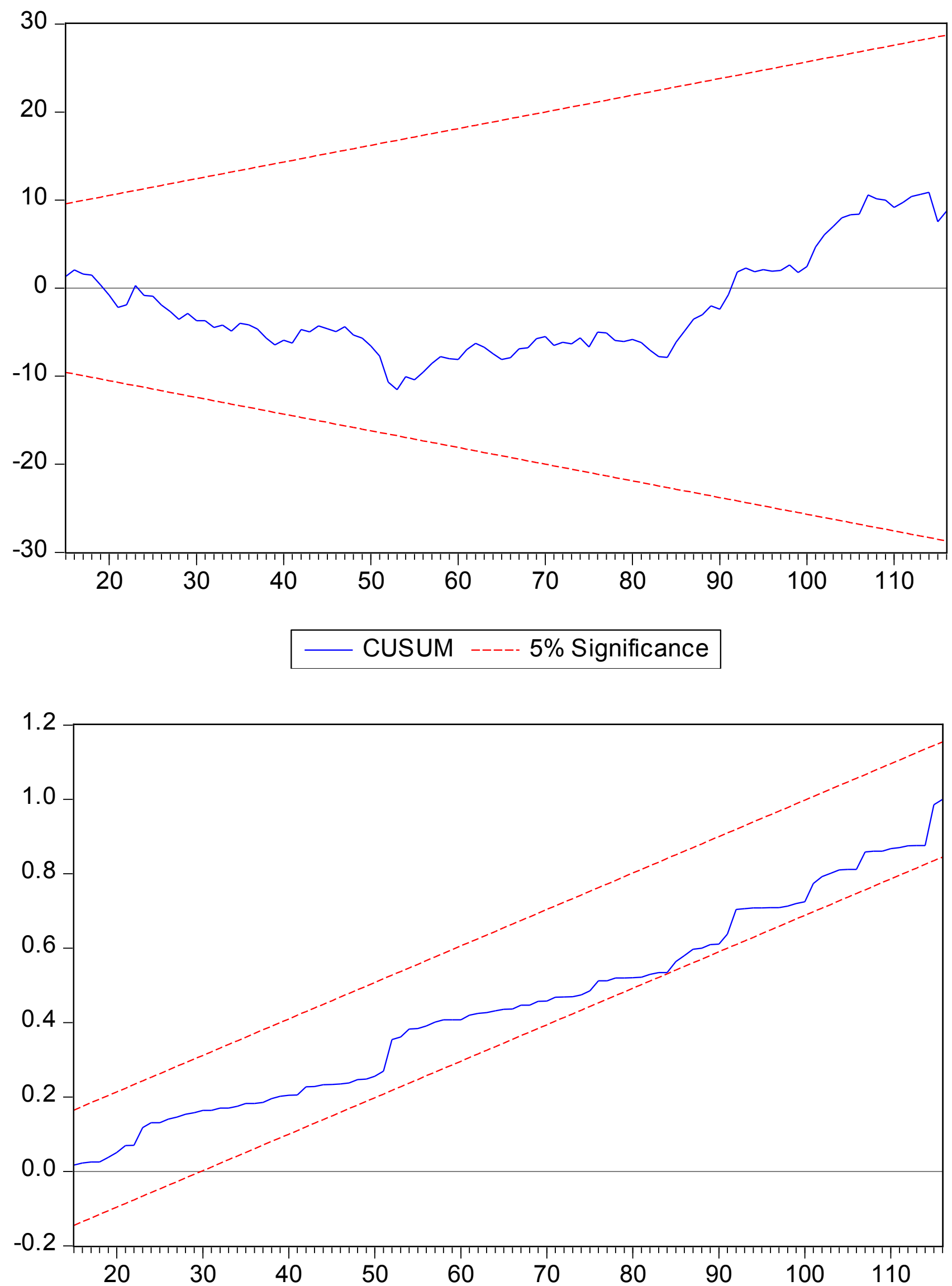

CUSUM of Squares ---- $5 \%$ Significance 


\section{Checking serial correlation and Heteroscedasticity}

Heteroscedasticity test was conducted using the Breuch-Pagan Godfrey test. F-statistics and its probability value is insignificant at 5\% significance value and supports Null hypothesis of no Heteroscedasticity.

Table 5

Heteroscedasticity

\begin{tabular}{|l|c|l|l|}
\hline Heteroscedasticity Test: Breusch-Pagan-Godfrey \\
\hline F-statistic & 1.545020 & Prob. F(7,105) & 0.1602 \\
\hline Obs*R-squared & 10.55226 & Prob. Chi-Square(7) & 0.1594 \\
\hline Scaled explained SS & 13.92694 & Prob. Chi-Square(7) & 0.0525 \\
\hline
\end{tabular}

\section{Serial Correlation LM Test}

This problem is tested using Breusch-Godfrey LM test in this study, for serial correlation the hypothesis is as follow.

Table 6

Breusch-Godfrey Serial Correlation LM Test

\begin{tabular}{|l|l|l|l|}
\hline F-statistic & 0.373069 & Prob. F(2,103) & 0.6895 \\
\hline Obs*R-squared & 0.812691 & Prob. Chi-Square(2) & 0.6661 \\
\hline
\end{tabular}

Breusch-Godfrey serial correlation LM Test shows that the P-value is more than $5 \%$ as shown in the above table. Therefore, the null hypothesis of no serial correlation in the residuals cannot be rejected, hence, the model has no serial correlation. So, our model has no serial correlation problem.

\section{DISCUSSION AND CONCLUSION}

The contuse increasing of COVID-19 pandemic generates shock waves on the crude oil markets, as well as in the real economy of US and also in the world. The deepness of the new economic recession will depend on the policy reaction to the coronavirus. The pandemic has generated important shockwave on commodity prices, including oil. The oil price which recorded the hardest cut after 1991, which help, for the moment, the economy of oil importing nations severely affected by the new coronavirus pandemic crisis. In this context, the purpose of our paper was to analyzes how the COVID-19 total death and total cases effect the US crude oil price.

The results of the study show that the world COVID-19 total death is significant impact on the crude oil price, if one percent increase in the total death in the world which lead decrees 
the crude oil price. The total cases of COVID-19 also have negative and significant effects the crude oil price. Albulescu [1] find that the COVID-19 effect on oil prices seems to be rather indirect, affecting first the financial markets instability. Future studies should explore the countries, data for COVID-19 and issues in depth.

\section{REFERENCES}

1. Albulescu, C. (2020). Do COVID-19 and crude oil prices drive the US economic policy uncertainty? arXiv preprint arXiv:2003.07591.

2. Albulescu, C. (2020). Coronavirus and financial volatility: 40 days of fasting and fear. arXiv preprint arXiv:2003.04005.

3. Ali, M., Alam, N., \& Rizvi, S. A. R. (2020). Coronavirus (COVID-19) - An epidemic or pandemic for financial markets. Journal of Behavioral and Experimental Finance, 100341.

4. Aloui, R., Gupta, R., \& Miller, S. M. (2016). Uncertainty and crude oil returns. Energy Economics, 55, 92-100.

5. Antonakakis, N., Chatziantoniou, I., \& Filis, G. (2014). Dynamic spillovers of oil price shocks and economic policy uncertainty. Energy Economics, 44, 433-447.

6. Barsky, R. B., \& Kilian, L. (2004). Oil and the Macro economy since the 1970s. Journal of Economic Perspectives, 18(4), 115-134.

7. Chen, X., Sun, X., \& Li, J. (2020). How does economic policy uncertainty react to oil price shocks? A multi-scale perspective. Applied Economics Letters, 27(3), 188-193.

8. Elder, J., \& Serletis, A. (2010). Oil price uncertainty. Journal of Money, Credit and Banking, 42(6), 1137-1159.

9. Gil-Alana, L. A., \& Monge, M. (2020). Crude oil prices and COVID-19: Persistence of the shock. Energy Research Letters, 1(1), 13200.

10. Laurenceson, J., \& Chai, J. C. (2003). Financial reform and economic development in China. Edward Elgar Publishing.

11.Liu, L., Wang, E. Z., \& Lee, C. C. (2020). Impact of the COVID-19 pandemic on the crude oil and stock markets in the US: A time-varying analysis. Energy Research Letters, 1(1), 13154.

12. Ma, S. K. (2018). Modern theory of critical phenomena. Routledge.

13. Monge, M., Gil-Alana, L. A., \& de Gracia, F. P. (2017). US shale oil production and WTI prices behavior. Energy, 141, 12-19.

14. Njindan lyke, B. (2020). The disease outbreak channel of exchange rate return predictability: Evidence from COVID-19. Emerging Markets Finance and Trade, 56(10), 2277-2297.

15. Narayan, P. K., Sharma, S., Poon, W. C., \& Wester Lund, J. (2014). Do oil prices predict economic growth? New global evidence. Energy Economics, 41, 137-146. 
16. Oil prices traded in negative territory for the first time as the spread of coronavirus (COVID-19) impacts demand. (Photo by Michael Heiman/Getty Images). Retrieved from: https://www.gettyimages.com/detail/news-photo/offshore-oil-platforms-are-seenon-april-20-2020-in-news-photo/1220026807.

17.Prabheesh, K. P., Padhan, R., \& Garg, B. (2020). COVID-19 and the oil price-stock market nexus: Evidence from net oil-importing countries. Energy Research Letters, 1(2), 13745.

18. Pesaran, M. H., Shin, Y., \& Smith, R. J. (2001). Bounds testing approaches to the analysis of level relationships. Journal of applied econometrics, 16(3), 289-326.

19. Pesaran, M. H., \& Pesaran, B. (1997). Working with Micro fit 4.0: interactive econometric analysis; [Windows version]. Oxford University Press.

20. Qin, M., Zhang, Y. C., \& Su, C. W. (2020). The Essential Role of Pandemics: A Fresh Insight into the Oil Market. Energy Research Letters, 1(1), 13166.

21.Zavadska, M., Morales, L., \& Coughlan, J. (2020). Brent crude oil prices volatility during major crises. Finance Research Letters, 32, 101078.

\section{INFORMATION ABOUT THE AUTHOR}

Shakil Ahmad (Pakistan, Mardan) - Graduate in Economics. Abdul Wali Khan University. E-mail: ShakilAhmadeco@gmail.com

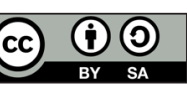

open 2 Access

Available: https://statecounsellor.wordpress.com/2021/02/24/ahmad/

Received: Jan 24, 2021 | Accepted: Feb 5, 2021 | Published: Mar 1, 2021

Editor: Mohamed R. Abonazel, PhD in Statistics and Econometrics. Cairo University, EGYPT

Copyright: (c) 2021 Ahmad, Sh. This is an open access article distributed under the terms of the Creative Commons

Attribution License, which permits unrestricted use, distribution, and reproduction in any medium, provided the original author and source are credited.

Competing interests: The authors have declared that no competing interests exist. 